\title{
Unmoderated Posters: Education
}

\begin{abstract}
UP-06
Validation of a Simulation-based Flexible Ureteroscopy Training Course and Novel Inanimate Ureteroscopy Training Model

Blankstein, Udi; Lantz, Andrea; Honey, R.J. D'A; Ordon, Michael; Pace, Kenneth; Lee, Jason Y.

St. Michael's Hospital, University of Toronto, Toronto, ON, Canada Introduction: Even the most advanced surgical simulator should be integrated into a comprehensive curriculum in order to maximize educational value. We designed a flexible ureteroscopy (fURS) simulation-based training course (SBTC) utilizing a novel inanimate training model (Cook ${ }^{\circledR}$ URS model) and present validity evidence for the Cook $($ URS model.

Methods: A comprehensive SBTC for fURS was designed for Jr-level (PGY13 ) residents at our institution. Baseline pre- and post-course assessments of fURS skill were conducted for a standardized task; fURS with basket manipulation of a lower pole stone into the upper pole. The pre- and post-test sessions were separated by a minimum of 2 weeks. Performances were video-recorded and reviewed by 2 blinded experts using a validated assessment device.

Results: A total of 10 residents participated in the fURS course. There was a significant improvement in both mean post-course task completion time ( 9.37 vs. 15.76 mins, $p=0.001)$ and performance score ( 25.25 vs. 19.20, $\mathrm{p}=0.007)$. Eighty percent of participants rated the Cook ${ }^{\circledR}$ URS model as realistic $(\geq 4 / 5$, mean $=4.20)$ and 5 independent expert endourologists rated
\end{abstract}

\begin{tabular}{|c|c|c|c|}
\hline & $\begin{array}{l}\text { Prior no. of } \\
\text { Flex URS }\end{array}$ & $\begin{array}{l}\text { Prior no. of } \\
\text { Flex Cysto }\end{array}$ & PGY level \\
\hline Overall score & $\begin{array}{c}0.453 \\
(p=0.04)\end{array}$ & $\begin{array}{c}0.545 \\
(p=0.01)\end{array}$ & $\begin{array}{c}0.314 \\
(p=0.18)\end{array}$ \\
\hline $\begin{array}{l}\text { Task completion } \\
\text { time (min) }\end{array}$ & $\begin{array}{c}-0.702 \\
(p<0.01)\end{array}$ & $\begin{array}{c}-0.500 \\
(p=0.03)\end{array}$ & $\begin{array}{c}-0.389 \\
(p=0.09)\end{array}$ \\
\hline Task pass rating & $\begin{array}{c}0.505 \\
(p=0.02)\end{array}$ & $\begin{array}{c}0.489 \\
(p=0.03)\end{array}$ & $\begin{array}{c}0.268 \\
(p=0.25)\end{array}$ \\
\hline Respect for tissue & $\begin{array}{c}0.360 \\
(p=0.12)\end{array}$ & $\begin{array}{c}0.230 \\
(p=0.33)\end{array}$ & $\begin{array}{c}0.220 \\
(p=0.35)\end{array}$ \\
\hline $\begin{array}{l}\text { Time and motion } \\
\text { efficiency }\end{array}$ & $\begin{array}{c}0.505 \\
(p=0.02)\end{array}$ & $\begin{array}{c}0.523 \\
(p=0.02)\end{array}$ & $\begin{array}{c}0.358 \\
(p=0.12)\end{array}$ \\
\hline Instrument handling & $\begin{array}{c}0.494 \\
(p=0.03)\end{array}$ & $\begin{array}{c}0.520 \\
(p=0.02)\end{array}$ & $\begin{array}{c}0.484 \\
(p=0.03)\end{array}$ \\
\hline $\begin{array}{l}\text { Handling of } \\
\text { ureteroscope }\end{array}$ & $\begin{array}{c}0.330 \\
(p=0.16)\end{array}$ & $\begin{array}{c}0.410 \\
(p=0.07)\end{array}$ & $\begin{array}{c}0.141 \\
(p=0.55)\end{array}$ \\
\hline $\begin{array}{l}\text { Flow of procedure } \\
\text { and planning }\end{array}$ & $\begin{array}{c}0.552 \\
(p=0.01)\end{array}$ & $\begin{array}{c}0.753 \\
(p=0.01)\end{array}$ & $\begin{array}{c}0.470 \\
(p=0.04)\end{array}$ \\
\hline Use of assistant & $\begin{array}{c}0.266 \\
(p=0.26)\end{array}$ & $\begin{array}{c}0.426 \\
(p=0.06)\end{array}$ & $\begin{array}{c}0.124 \\
(p=0.60)\end{array}$ \\
\hline $\begin{array}{l}\text { Knowledge of } \\
\text { procedure }\end{array}$ & $\begin{array}{c}0.441 \\
(p=0.05)\end{array}$ & $\begin{array}{c}0.510 \\
(p=0.02)\end{array}$ & $\begin{array}{c}0.315 \\
(p=0.18)\end{array}$ \\
\hline
\end{tabular}

the model as useful as a training device $(\geq 4 / 5$, mean $=4.90)$, providing good face and content validity. The Cook ${ }^{\circledR}$ URS model demonstrated excellent construct validity; there was significant correlation $(p<0.05)$ between prior fURS experience and mean overall performance scores, task completion times, passing ratings, movement efficiency, instrument handling, and flow of procedure scores (Table 1). The fURS global rating scale demonstrated good reliability (Cronbach's alpha $=0.848)$.

Conclusions: Our study demonstrates that our SBT curriculum for fURS can lead to improved short-term technical skills amongst junior level urology residents. The Cook $\mathbb{R}$ URS model demonstrated face, content and construct validity.

\section{UP-07}

\section{Study Habits of Canadian Urology Residents}

Skinner, Thomas; Touma, Naji

Department of Urology, Queen's University, Kingston, ON, Canada

Introduction and Objectives: Urology residency in Canada consists of 5 years of structured clinical training culminating in a summative licensing exam. Small studies have investigated resident study habits and performance on surgical in-training examinations, but no data on Canadian Urology residents exist. We explored how Canadian Urology residents study during their training.

Methods: A cross-sectional survey was administered to all final-year Canadian Urology residents over a two-year period 2013 and 2014. The participation rate was $100 \%$. Survey questions address study habits in each stage of training and focus on studying time, motivators, resources utilized, study methods and satisfaction with training environment.

Results: The first 31 questionnaires have been analyzed. Respondents have indicated that the volume and structure of their studying increased throughout residency. Over $50 \%$ of respondents denied dedicated study time in junior years, whereas $70 \%$ of respondents reported $>10$ hours/week in their final year with $32 \%$ spending $>20$ hours/week. Motivation for studying shifted with seniority, from preparation for clinical duties to Royal College exam preparation. In the final year of training, $97 \%$ of respondents indicated that exam preparation was the biggest motivator. Considerable variability exists in the studying methods used, especially amongst junior residents. While a variety of resources were utilized throughout training, Campbell's Urology was the overwhelming choice for chief residents, with $>80 \%$ reporting that it was very useful.

Conclusions: The Royal College licensing exam constitutes a great motivator for trainees as indicated by amount of studying and resources used at different levels of training. Consideration may be given to instituting several exams throughout training to spur motivation for studying during the junior years of training. 